\title{
Liberalism vs. Marxism-Leninism and the Future of Education in South Africa
}

\author{
Moeketsi Letseka \\ College of Education, University of South Africa \\ E-mail: letsem@unisa.ac.za
}

\section{Doi:10.5901/mjss.2013.v4n3p67}

\begin{abstract}
This paper debates the ideological tension in South Africa between, one the one hand, liberalism, and, on the one hand both the radical Africanist Black Consciousness Movement (BCM) of the 1970s, and the hard-line Marxism-Leninism inclined South African Communist Party (SACP) and the Congress of South African Trade Unions (COSATU). The paper's central argument is, on the one hand, that the BCM's criticisms of liberalism were specific to South Africa's white liberals and to specific historical moment on the 1970s. On the other hand the SACP and COSATU's hard-line Marxism-Leninism is pitted against the African National Congress's (ANC), which is more community oriented and less attuned to the aspirations of organised labour like its partners. And given that the ANC is in the majority and has more or less hegemonised the alliance the threat to liberalism posed by both the radical Africanist BCM and the hard-line Marxism-Leninism of both the SACP and COSATU haS been nullified. It can therefore be reasonably argued that South Africa's project of a liberal conception of education will be sustained in compliance with the country's liberal and egalitarian Constitution.
\end{abstract}

Keywords: South Africa, liberalism, Liberal education, Marxism-Leninism, South African Communist Party, Congress of South African Trade Unions, Black Consciousness Movement.

\section{Introduction}

From time immemorial liberalism has either been celebrated and defended (Gaus, 2000; Gutmann, 1985, Rawls, 1999), or contested (Abbey, 2005; Abbey, 2004; Cobbah, 1987; Gray, 1978), scoffed at and reviled (Biko, 2005; Makgoba, 1998; Ake, 1993). For instance, on the one hand Gaus (2000:180) posits that "the twentieth century was a surprisingly liberal century ....Consensus on the pre-eminence of the liberal ideals of liberty and markets appears well-nigh universal". He argues that by the close of the twentieth century "liberalism has apparently defeated, or has certainly got the upper hand on, its traditional rivals" (Gaus, 2000:195). While Gutmann (1985:310) mounts a defence against claims that "liberal politics is philosophically indefensible". That there is such a wide diversity of views on liberalism is not unusual. Evans (1999:117) contends that "being aware of the great diversity within the liberal tradition, no sensible liberal would be prepared to offer a substantial and rigidly specified characterisation of that which makes a doctrine "liberal". In the same vein Holmes (1995:13) observes that "the political theorists who have most cogently articulated and defended liberal aspirations - Milton, Spinoza, Locke, Montesquieu, Hume, Voltaire, Beccaria, Blackstone, Smith, Kant, Bentham, Madison, Hamilton, Constant, Tocqueville, and J. S. Mill - were deeply immersed in contemporary controversies. Each spent his life responding to local challenges, defending specific reforms, struggling with circumscribed problems". Holmes argues that "their epistemologies and metaphysical beliefs were sometimes diametrically opposed to each other's. They also deviated from one another on a wide range of policy questions". As a result "none can be fully understood if plucked ahistorically from his political and intellectual context and forced to march in a canonical parade of liberal greats".

Like their predecessors above, contemporary political theorists are also grappling with controversies and contestations around various conceptions and articulations of liberalism (Galston, 2005, 1991; Rawls, 1999, 1996; Waldron, 1987; Enslin, 1986; Berlin, 1969). It is now clear that even though liberalism does not feature in William B. Gallie's (1956) list of "essentially contested concept" the bottom line is that liberalism is not only a contested concept (Abbey, 2005; Gray, 1978), but it is also a 'complex' concept (Simhony, 2003). Some commentators have even made reference to "a family of liberalisms" (Simhony, 2003:283), "a multitude of liberalisms" (McKay, 2000:627), as well as to "many liberalisms" (Rawls, 1996:223) as evidence of the proliferation of the term. These varieties only go on to underscore the complex and contested nature of liberalism as a social science concept.

In 1996 South Africa adopted a Constitution that has been described as "a model liberal democratic constitution that has few peers in the world community" (Jordan, 1996); that bears "the hallmarks of liberal democracy" (Enslin and 
Horsthemke, 2004:552; Dugard, 1998:23), and "is widely hailed as liberal and egalitarian" (Deveaux, 2003:162), because "it values human dignity and frames human rights at its heart" (Robinson, 2012:2). South Africa's ruling tripartite alliance of the African National Congress (ANC), the South African Communist Party (SACP), and the Confederation of South African Trade Unions (COSATU) is an alliance of fascinating dynamics. The SACP and COSATU are strongly influenced by, and commit to framing their political direction by the principles of Marxism-Leninism. Under normal circumstances this radical Marxist-Leninist leaning of the ruling alliance's partners would be deemed incompatible with South Africa's much vaunted liberal aspirations. When we consider that the General Secretary of the SACP is South Africa's current minister of the Department of Higher Education and Training (DHET), the challenges of theorising South Africa's political landscape and education become even more porous. Does this imply a radical policy shift towards a Marxist-Leninist conception of education in South Africa? Of course such a question would be dismissed as counter revolutionary capitalist rhetoric in countries such as China or the Soviet Union where the General Secretary of the Communist Party is the all-powerful party leader who is well placed to influence educational policy to fit in with the party's Marxist-Leninist ideology. But what are the implications of this scenario for an emergent liberal democracy like South Africa? I shall argue that this scenario does not pertain to South Africa for two crucial reasons. First, the ANC, which is in the majority, has hegemonised the alliance. And second, the ANC is more community oriented and less attuned to the aspirations of organised labour like its partners.

This paper is structured around five sections. I start by sketching what liberals generally value, and about which most liberal democracies will promulgate laws to ensure that such values are promoted, defended and sustained. Second, I explore the view that liberalism is not only a 'complex' social science concept, but that it also falls under the category of those concepts that have been described as 'essentially contested'. Third, I draw on the 'complex' and 'contested' nature of liberalism to unpack the liberal tradition in South Africa. It shall become clear from this unpacking that South Africa's liberal tradition has its own context-specific historical nuances that make it even more fascinating to engage and analyse. In the fourth section I tease out the influence of Marxism-Leninism among two members of South Africa's majority ruling tripartite alliance that is made up of the ANC, the SACP, and COSATU, and speculate on the implications of this influence on South Africa's liberal aspirations. The pertinence of this speculation cannot be overemphasised given that South Africa boasts of a Constitution that is widely regarded as liberal and egalitarian. In the fifth and final section I offer some concluding remarks.

\section{Basic Principles that Liberals Value}

Enslin (1984:3) posits that "the necessary and most fundamental formal characteristic of liberal ideas is that they defend the principle of liberty or freedom". Waldron (1987:130) elaborate: "liberty is a concept which captures what is distinctive and important in human agency as such and in the untrammelled exercise of powers of individual deliberation, choice, and the intentional initiation of action". Historically liberal political philosophy has been associated with the Enlightenment. For Waldron (1987:134), "the relationship between liberal thought and the legacy of the Enlightenment cannot be stressed too strongly. The Enlightenment was characterised by a burgeoning confidence in the human ability to make sense of the world, to grasp its regularities and fundamental principles, to predict its future, and to manipulate its powers for the benefit of mankind". Waldron contends that "after millennia of ignorance, terror, and superstition, cowering before forces it could not understand nor control, mankind faced the prospect of being able at last to build a human world in which it might feel safely and securely at home".

Gray (1995:17) concurs: "throughout the latter half of the eighteenth century, the history of liberalism in continental Europe and the spread of the Enlightenment must be regarded as aspects of one and the same current of thought and practice". For Gray (1995:71-72), "the sine qua non of the liberal state in all its varieties is that governmental power and authority be limited by a system of constitutional rules and practices in which individual liberty and the equality of persons under the rule of law are respected". Waldron (1987:130) endorses Gray's view above. He argues that "in politics, liberals are committed to intellectual freedom, freedom of speech, association, and civil liberties generally. In the realm of personal life, they raise their banners for freedom of religious belief and practice, freedom of lifestyle, and freedom (provided again that it is genuine freedom for everyone involved) in regard to sexual practices, marital affairs, pornography, the use of drugs and all those familiar liberal concerns". Thus, "liberals insist on the importance of rights, including the right of people to practice their religion as they see fit, to speak for and assemble around causes in which they believe, and to possess a significant degree of control over their personal livelihood" (Wolfe, 2009:11). Wolfe (2009:11) posits that "liberals believe that individuals live within an ordered world that necessarily constraints the ability of people to do whatever they want whenever they want to do it". However, he is quick to point out that for liberals, "such 
constraints are not imposed by authorities over which people have no control or shaped by traditions they cannot influence; they are established instead by people themselves through some form of consent or social contract. Independence cannot exist without interdependence".

Cobbah (1987:312) contends that "the political philosophy of liberalism was largely a reaction to medieval thought. It was a philosophical opposition to traditional authority that was based on divine wisdom, religion, and the common law". For Cobbah (1987:313), it was Thomas Hobbes who introduced the idea of human rights as a conception of human nature in which individuals possessed natural rights to all the objects of their desire. Cobber (1987:312) notes that Hobbes conceived of a right as the "liberty each man has to use his own power as he will himself, for the preservation of his own nature - that is to say, his own life". In the same vein John Locke (1993) rejected medieval notions of authority and envisioned individuals stripped of all historical loyalties and beliefs, pursuing their security, within a community in which they could appoint a ruler, who would govern subject to remaining acceptable to the community. Similarly, Susser (1995:59) argues that "liberalism represented a revolt of the rising urban middle class of merchants and entrepreneurs against the pre-modern alliance of throne, sword, and alter - the absolute monarchy, the feudal aristocratic order, and the vast powers of the church". This reason for this is fairly simple. Liberalism is "a theory about what makes political action and in particular the enforcement and maintenance of a social and political order - morally legitimate" (Waldron, 1987:140). Suffices it to mention that as a social science concept liberalism is not only a 'complex' concept (Simhony, 2003), but it is also an 'essentially contested concept' (Gallie, 1956). In the next section I explore these complexities and contestations.

\section{Liberalism as 'Complex' and 'Essentially Contested Concept'}

As a cautionary note I should mention that liberalism does not feature in Gallie's (1956) list of 'essentially contested concepts'. ${ }^{1}$ Abbey (2005:468) argues that "with concerns about democracy on the ascendancy...the concept of liberty or more accurately, of particular liberties deserving protection irrespective of their democratic spread or appeal, appears steadily to have lost ground". But I want to argue that this is debatable. As Ware (1992:130) points out, "since the 1950s political scientists attempted to develop classifications of liberal democratic regimes... It was commonplace to distinguish between Anglo-American and Continental European political systems". Evidence from the literature points to vigorous debates on liberalism from the 1930's onwards through to the 1950s. For instance, on $28^{\text {th }}$ December 1934 a symposium was held during the meeting of the Eastern Division of the American Philosophical Association at New York University where John Dewey, William Ernest Hocking, W. M. Pepperell Montague, Morris Cohen, C. M. Bakewell, Sidney Hook, and John Herman Randall, Jr., debated 'The Future of Liberalism'. The papers from the symposium were subsequently published in Journal of Philosophy and International Journal of Ethics in 1935 and in Western Political Quarterly in 1948. Books published on liberalism during this period include John Dewey's (1935) Liberalism and Social Action; Harold Laski's (1936) The Rise of Liberalism; William Beveridge's (1945) Why I am a Liberal, and Morris Cohen's (1946) The Faith of a Liberal. In 1949 Gallie himself published the paper "Liberal morality and socialist morality" in the journal Philosophy, which elicited critical responses from T. B. Bottomore and Helen Wodehouse in the same journal in 1950.

Abbey's (2005:468) view is that liberalism "qualifies as an 'essentially contested concept' because it approximates Gallie's criteria as closely as the examples he offers do". Abbey (2005:462) contends that "as more and more political theorists locate themselves within the liberal fold, the meaning of the term liberalism has widened and the construction of the liberal tradition has become increasingly contested". Thus "the question of what liberalism is has become more intensely debated by those who consider themselves liberals" (Abbey, 2005:463). As Philp (1996:391) elaborates, "some liberals take preferences in the form of a utility function, others start from the person as having 'reasonable' demands upon the political process, still others start from an antecedent conception of the self as a rights bearer or moral subject, and communitarian liberals start from a view of the subject as embodying the values and principles of his or her community". I want to argue that the route South Africa is taking is of the self as a rights bearer or moral subject, while embracing the values and principles of his or her community.

For Abbey (2005: 468-469), liberalism approximates Gallie's criteria in at least four ways. First, "in most contemporary English-language political theory, the term liberalism is used in the positively appraisive way required by Gallie". Second, "liberalism is an internally complex phenomenon". For instance, "liberty, equality, rationality, individual dignity, rights, justice, autonomy, consent and the priority of the right over the good" are among liberalism's constituent

1 In his formulation of "essentially contested concepts" British philosopher William B. Gallie (1956) lists art, democracy, social justice, and Christian life as 'essentially contested concepts'. Gallie (1956:169) argues that 'essentially contested concepts' are those "concepts the proper use of which inevitably involves endless disputes about their proper uses on the part of their users". 
elements. Third, these elements are however, "susceptible to being ordered in different ways". And fourth, "liberalism is a vague and open-ended concept". It offers "the possibility of an inherently dynamic approach to politics and society in that it provides society with the possibility of, and justification for continuously remaking itself". For Abbey (2005:469), "this dynamic quality derives from the abstract and universal nature of ideals that lie at the heart of liberalism - liberty, equality, autonomy and toleration". It is Abbey's contention that "by promising equal freedom to all in the shaping of their own lives and pursuit of their own conception of the good (subject to caveats like the harm principle), liberalism offers the normative resources for constant challenges to the status quo".

In the introduction I alluded to the fact that liberalism is not only an 'essentially contested concept' as the above analysis shows, but that it is also a concept that is laden with complexities. Friedman (2003:182) posits that "equality, rights, autonomy, justice, and liberty are all variously interpreted by liberals themselves. Liberalism is no more monolithic or homogeneous than are the minority cultures that sometimes challenge the authority of liberal governments". Friedman's observation echoes Abbey (2005) and Philp (1996) above that what liberalism is has become more intensely debated by those who consider themselves liberals. For Friedman (2003), "what are called 'liberal values and principles' are simply values and principles that happen to figure prominently in many versions of liberal ideology today, but that could be defended from any number of philosophical points of view". Indeed Simhony (2003:283-284) warns that "to talk of 'standard' liberalism is not helpful to appreciating the variety of liberalism". He contends that "complexity is lost when we approach liberal argument from a discourse of simple oppositions". I now turn to the liberal tradition in South Africa.

\section{South Africa's Liberal Tradition}

Writing on the specific liberal tradition in South Africa David Welsh (1998:1-2) identifies the following as "the core values of liberalism": a commitment to fundamental human rights and those procedural safeguards known as the rule of law; a commitment to constitutionalism, meaning that the state and government are to operate under law and that certain fundamental principles must remain beyond the reach of any (temporary) government; ${ }^{2}$ a belief in equality (whose exact parameters remain a matter of on-going debate, but implying at least equality before the law) and (for most liberals) the dismantling of entrenched political, economic, and social inequalities; an emphasis on the primacy of the individual as the possessor of inalienable rights, though by no means, as critics allege, unmindful of the need for, and claims of, community; tolerance of conflicting viewpoints (spelled out with force in John Stuart Mill's essay On Liberty). Tolerance is perhaps the logical consequence of the right to freedom of expression, but its centrality in liberal thinking requires that it be regarded as a separate principle; an optimistic belief in the possibilities of individual and social 'improvement' with the implication that no individual, community, or society is irretrievably damned as hopeless; and compassion.

Welsh underscores the core values of classical conceptions of liberalism, for instance, tolerance of conflicting viewpoints as articulated by Mill. Most importantly he acknowledges South Africa's communal imperatives with his emphasis on community. It is my view that community [however this is conceived] is an essential component of the liberal tradition. Indeed there is consensus among some liberals that "liberalism is itself a form of community" (Galston, 1991:43), whose members "excel in liberal virtues and as a consequence, flourish in a distinctively liberal way" (Macedo, 1991:278). Some liberals have suggested that "liberalism supplies the best interpretation of a political community" (Dworkin, 1989:480), that "the lives of individual people and that of their community are integrated", and that "the critical success of any one of their lives is an aspect of, and so is dependent on, the goodness of the community as a whole" (Dworkin, 1989:491), while others have argued that "the inseparability of rights and community is a consistent liberal position" (Simhony, 2003:271). As Abbey and Taylor (1996:3) point out, "it is possible for someone to have a communitarian or holist ontology and to value liberalism's individual rights". However, in my view Mulhall (1987: 275) is spot on in his endorsement of the place of the individual in a community when he argues that the liberal "need have no difficulty in accepting the constitutive role of community membership". Mulhall further argues that "liberals must indeed affirm that the political community's institutions embody a vision relating to personhood, i.e. they must affirm that such institutions protect that capacity which makes an individual citizen a human agent and so refer to a capacity which every citizen must be supposed to possess if he is to be seen as a person at all".

Notwithstanding these lofty liberal values South Africa's liberal tradition has been described as "diffused and lacking in organisational focus" (Welsh, 1998:1). It continues to be "widely derided, or at best ignored as irrelevant to

\footnotetext{
2 Welsh's (1998) second core value of liberalism above resonates with section 9 (3), chapter 2 of the Bill of Rights in the Constitution of South Africa, which reads as follows: "The state may not unfairly discriminate directly or indirectly against anyone on one or more grounds, including race, gender, sex, pregnancy, marital status, ethnic or social origin, colour, sexual orientation, age, disability, religion, conscience, belief, culture, language and birth".
} 
South African affairs" (Enslin, 1999:180). Makgoba (1998:284) is unequivocal that South Africa's white liberals remain "unpopular because in the eyes of the majority and the international community they are subtle racists". It is worthwhile mentioning that liberalism "has never been a dominant force in South African politics" (Waghid, 2003:81).Yet, and ironically, "political organisations like the National Party and the ANC, neither of whom could be described as liberal, could agree on an essentially liberal form of state" (Welsh, 1998:28).

In the 1970s Steve Biko, leader of the Black Consciousness Movement (BCM) who died in police custody in 1977 while detained under the Terrorism Act of 1967 was scathing towards South Africa's white liberals. I must preface my use of Biko's views in this paper by mentioning his ideas should be understood in the historical context of the Black Consciousness Movement (BCM), which he led during the 1970s. The 1970s was the era of militaristic and authoritarian apartheid rule in South Africa. What then is Black Consciousness? Biko (1972:6) defined it as follows:

\begin{abstract}
"In essence this is an attitude of mind and a way of life. It is the most positive call to emanate from the Black world for a long time. Its unadulterated quintessence is the realisation by the Black man of the need to rally together with his brothers around the cause of their oppression - the blackness of their skin - and to operate as a group in order to rid themselves of the shackles that bind them to perpetual servitude. It is based on a self-examination which has ultimately led them to believe that by seeking to run away from themselves and to emulate the White man they are insulting the intelligence of whoever created them Black".
\end{abstract}

Biko (2005:91) used the thesis, antithesis, and synthesis dialectic to mound the most scathing and vicious attack on South Africa's white liberals. For instance, he noted that "the thesis, the antithesis and the synthesis have been mentioned by some great philosophers as the cardinal points around which any social revolution revolves. For the liberals, the thesis is apartheid, the antithesis is non-racialism and the synthesis very feebly defined". Biko argued that "Black Consciousness defines the situation differently. The thesis is in fact a strong white racism and therefore, the antithesis to this must, ipso facto, be a strong solidarity amongst the blacks on whom this racism seeks to prey. Out of these two situations we can therefore hope to reach some kind of balance - a true humanity where power politics will have no place". Biko argued that the failure of the liberals lay in fact that their antithesis was a watered-down version of the truth whose close proximity to the thesis will nullify the purported balance.

Biko (2005:20) argued that South Africa's liberals insist that "they are not responsible for white racism and the country's 'inhumanity to the black man'. These are the people who claim that they too feel the oppression just as acutely as the blacks and therefore should be jointly involved in the black man's struggle for a place under the sun. In short, these are the people who say that they have black souls wrapped up in white skins". Biko was contemptuous towards white liberals' insistence that the problems of the country could only be resolved by a bilateral approach involving both black and white. He queried that "the integration they talk about is first of all artificial in that it is a response to conscious manoeuvre rather than to the dictates of the inner soul.... the people forming the integrated complex have been extracted from various segregated societies with their inbuilt complexes of superiority and inferiority and these continue to manifest themselves even in the "non-racial' set-up of the integrated complex". Thus "the integration so achieved is a one-way course, with the whites doing all the talking and the blacks the listening".

For Biko (2005:22), South Africa's white liberals were only playing games. He argued that "they are claiming a 'monopoly on intelligence and moral judgment' and setting the pattern and pace for the realisation of the black man's aspirations. They want to remain in good books with both the black and white worlds. They want to shy away from all forms of 'extremisms', condemning 'white supremacy' as being just as bad as 'Black Power!'. They vacillate between the two worlds, verbalising all the complaints of the blacks beautifully while skilfully extracting what suits them from the exclusive pool of white privileges". Biko did not find any honesty in white liberals' anti-apartheid protests. He argued that "their protests are directed at and appeal to white conscience, everything they do is directed at finally convincing the white electorate that the black man is also a man and that at some future date he should be given a place at the white man's table". In the penultimate section below I broach into the influence of Marxism-Leninism in South Africa's political landscape and raise some questions regarding the plausibility of liberalism in a political environment where liberalism and Marxism-Leninism are in contention for political and ideological turf.

\title{
The Influence of Marxism-Leninism
}

There is a deep ideological chasm between South Africa's liberal tradition and the ideological orientation of the SACP and COSATU. The latter two organisations are key partners in the ruling tripartite alliance with the ANC. In its Constitution, which was amended at the $13^{\text {th }}$ National Congress in July 2012, the SACP (2012:3-4) states that "in leading the working 
class towards national and social emancipation, the SACP is guided by those principles of Marxism-Leninism whose universal validity has been proven by historical experience". It declares that "in applying the general principles of Marxism-Leninism, the SACP is, in the first place, concerned with their indigenous elaboration and application to the concrete realities of our own developing situation" (SACP, 2012:4).

The SACP states that it seeks to end the system of capitalist exploitation in South Africa and to establish a socialist society based on the common ownership of, participation in, and control by the producers of the key means of production; to organise, educate and lead the working class in the struggle for socialism and the more immediate objectives of defending and deepening the national democratic revolution and of achieving national and social emancipation; to organise, educate and advance women within the working class, the poor and rural communities in pursuit of the aims of the SACP; to raise the consciousness of the working class and its allies around the integral and oppressive nature of gender relations within South African capitalism; to combat racism, tribalism, sex discrimination, regionalism, chauvinism, xenophobia and all forms of narrow nationalism, and to promote the ideas of proletarian internationalism and the unity of the workers of South Africa and the world.

But some of the SACP's statements and declarations warrant a critical response. For instance, the SACP states that it endeavours to "educate and lead the working class in the struggle for socialism and the more immediate objectives of defending and deepening the national democratic revolution and of achieving national and social emancipation". And yet concerns have been raised about some of SACP and other liberation struggle leadership whose lives of opulence in the cosmopolitan suburbs of South African cities are in direct contradistinction to the lives of the ordinary workers they claim to represent. For instance, Bekker (1998: 47) argues that "many of the new black elite - comrades in business have been visibly seduced by capitalist creed and are, accordingly, losing the moral high ground of struggle politics", while Mathebe (2010:17) observes that "many political leaders in South Africa are losing the tune of batho pele (people first), defected from their original positions for the love of money and self-enrichment". University of Cape Town political scientist Anthony Butler (2013) challenges the SACP leadership to come clean and acknowledge that it has deviated from its original ideological position: "the SACP is now in government. It is seeking not to destroy the capitalist state but rather to use it as an instrument of economic development. The party has therefore abandoned Marx". The General Secretary of the National Union of Metalworkers of South Africa (NUMSA), which is also an affiliate of COSATU has lamented that senior members of the SACP pontificate that "the South African state is not a bourgeois-democratic dictatorship", and yet the South African state remains "one of the most brutal and backward capitalist states" (Butler, 2013).

The SACP states that it seeks to "advance women within the working class". And yet at its $13^{\text {th }}$ National Congress where office bearers were elected for the 2012-2017 political term only one female, Joyce Molio-Moropa, was elected to the position of party National Treasurer. The rest of the office bearers, the General Secretary: Blade Nzimande, First Deputy General Secretary: Jeremy Cronin, Second Deputy General Secretary: Solly Afrika Mapaila, National Chairperson: Senzeni Zokwana, Deputy National Chairperson: Thulasi Nxesi, are all males. Even the party's Central Committee, which comprises thirty five (35) members, there are only ten (10) females (SACP Media Release, 14 July 2012).

It should come as rather unusual that there is no mention of 'Marxism-Leninism' or 'national democratic revolution' in COSATU's Constitution (2006). However, this should not obscure the fact that COSATU and the SACP have a symbiotic ideological relationship. For instance, in their public speeches at various regional forums and national congresses of affiliated unions the leadership of COSATU publicly declares the labour federation's commitment to Marxism-Leninism. Case in point: in a speech delivered at the $4^{\text {th }}$ International Police Symposium which was held in Lusaka, Zambia, from $27^{\text {th }}-30^{\text {th }}$ April 2013, COSATU's president informed the delegates that "as COSATU we approach issues from a Marxist - Leninist perspective". He prefaced his address "by summoning from the grave Louis Althusser on 'Ideology and Ideological State Apparatus'" (Dlamini, 2013:2). He argued that Althusser's article "captures what I consider to be the main content of our discussion today because we have come here to discuss Advancing Sound Labour Relations in Policing and Correctional Services within the African Continent. But comrades as you are all aware, this theme is not innocent or neutral. It is about how the police also function by ideology both to ensure their own cohesion and reproduction, and in the 'values' they propound externally" (Dlamini, 2013:3).

In another address, this time to the National Union of Mineworkers' (NUM) national congress which was held on 25 May 2011 at Emperor's Palace, Ekurhuleni, COSATU's president once again reiterated the federation's commitment to Marxist-Leninism: "As Marxist-Leninists we should shift away from a false belief that history is made by 'Great Men and Women', kings and queens, statesmen and politicians. As Marxist-Leninists we are opposed to this unscientific approach, but we do not deny the role of individuals in history, their initiative or audacity (or lack of it), in the social struggle" (Dlamini, 2012:5). The COSATU president informed the NUM congress that "our revolution has reached a stage 
where we need to invest our resources into building the capacity and political resourcefulness of our shop stewards based on advancing our class interests". Part of this task, he argued, "includes building the SACP as our vanguard" (Dlamini, 2012:6). By declaring the SACP the vanguard of COSATU the labour federation's president was echoing Lenin's (1999:22) view on the Communist Party as the "vanguard of the proletariat, its class-conscious section", which he succinctly delineates in one of his political treatises, Left-Wing Communism: Infantile Disorder. Lenin (1999:26) argues that "the united-front tactic, like all the tactics employed by the Marxists, is aimed at facilitating the creation of a revolutionary vanguard party capable of educating, organising and mobilising the working - class masses to carry out a proletarian revolution and the building of the classless socialist society".

But what is the genesis of COSATU and the SACP's Marxist-Leninist orientation? Buhlungu and Ellis (2012:274) argue that "for more than four decades after the Second World War, South African communists enjoyed the support of a superpower and espoused a political programme strongly influenced by the Soviet style of Marxism-Leninism. The immediate goal was the overthrow of apartheid through a national democratic revolution. As long as the Soviet Union existed, the SACP could be sure that it would, via its relationship with the ANC and the preponderance of its members in the ANC leadership, be in a position of considerable strength to embark on the next phase of the revolution, the transition to socialism". From the SACP's Constitution above it is clear that the party "remains firmly wedded to an Orthodox Marxism-Leninism, while acknowledging some of the failings and excesses of the actual experience of the Soviet Union" (Buhlungu and Ellis, 2012:276).

Should we be worried about the prospects of liberalism in South Africa? That is, is the country's project of a political future based on the amalgam of traditional African values and liberal values now in vain? What are the implications for a liberal conception of education given that the General Secretary of the SACP is also South Africa's minister of the Department of Higher Education and Training (DHET)? Does this imply a radical policy shift towards a Marxist-Leninist conception of education in South Africa? Such questions would no doubt be dismissed as mere counter revolutionary capitalist rhetoric in countries such as China or the Soviet Union where the General Secretary of the Communist Party is the all-powerful party leader who is well placed to influence educational policy to fit in with the party's Marxist-Leninist ideology. My own view is that the above scenario might not pertain to South Africa for two reasons. First, while the SACP and COSATU are key partners in the ruling alliance, the ANC calls the shots. As mentioned above the ANC is more community orientated and less attuned to the aspirations of organised labour like its alliance partners. And most importantly, the ANC has more or less "hegemonised the alliance".

Second, the Constitution of South Africa is the supreme law of the land by which everyone is bound, and with which the disparate political parties and their disparate ideologies are obliged to comply. Arthur Chaskalson (2003:599600), the first Chief Justice of post-apartheid South Africa's Constitutional Court who served during Nelson Mandela's presidency contends that "the new South African Constitution is a moral document. Even a cursory reading of its provisions demonstrates this. It is the supreme law, and law or conduct inconsistent with its provisions is invalid". He notes that "the preamble to the Constitution identifies constitutional goals that include establishing a society based on democratic values, social justice and fundamental human rights. Key to this is the Bill of Rights, contained in chapter 2 of the Constitution, which is a cornerstone of democracy in South Africa. It enshrines the rights of all people in our country and affirms the democratic values of human dignity, equality and freedom". Richard Goldstone (1997: 454), another former judge of the Constitutional Court who went on to serve in the International Court of Justice at the Hague argues that to say the Constitution is the supreme law of the land means that "the Court's power to interpret and enforce the Constitution, guarantee an independent, impartial, and appropriately qualified judiciary is protected; that universally accepted fundamental rights are entrenched; that the independence and impartiality of certain state institutions are ensured; that universal adult franchise and proportional representation are protected; and that existing provincial powers in relation to the state have some protection".

South Africa's political scene is ironic. While we recognise the potential threat of Marxist-Leninism to liberalism, we are also cognisant that such a threat might not result in a radical shift towards hard-line Marxism-Leninism. This is because Marxism-Leninism is a contested ideological position in the tripartite alliance. The ANC, which has the majority is not inclined to Marxism-Leninism. Summing up David Welsh's (1998) introductory remarks in the book Ironic Victory: Liberalism in Post-apartheid South Africa, Yusef Waghid (2003:14) argues that "many liberals who believe in the values of human dignity, the achievement of equality, the advancement of human rights and freedoms, non-racialism, nonsexism, supremacy of the rule of law, universal adult suffrage, a national common voters roll, regular elections and a multi-party system of democratic government with the aim to ensure accountability, responsiveness and openness, would certainly consider the Constitution of the Republic of South Africa of 1996 as an 'ironic victory"'. It seems that Gaus (2000:179-180) is right after all that despite fears that "the prospects for liberalism had dimmed"; that "liberalism could 
gradually sink", or that "its days were numbered", liberals at the turn of the century "may understandably feel entitled to celebrate"

\section{Conclusion}

In this paper I debated the tension between the ideological positions of, one the one hand, liberalism, and, on the one hand the radical Africanist BCM, and on the other hand the hard-line Marxism-Leninism inclined SACP and COSATU. In view of these oppositional ideological camps I raised question on the plausibility of liberalism in South Africa given that South Africa's political landscape is predicated on the Constitution which is widely recognised as liberal and egalitarian. While it is not my intention in this paper to downplay the force of the radical Africanist BCM I argued that its ideas have to be viewed within the historical moment [the 1970s] during which they gained currency and were a force to reckon with. I also highlighted the fact that the BCM's criticisms of liberalism were context-specific to South Africa's white liberals in that historical moment. I argued that they did not generally nullify the worth of liberalism as a political theory.

I unpacked the ideological turf war between, on the one hand, the Marxist-Leninist inclined SACP and COSATU, and on the other hand the more community-oriented ANC, with a view to ascertaining whether this turf war can potentially frustrate South Africa's liberal aspirations. I surmised that given that the ANC, which holds all the aces has hegemonised the alliance and is more community oriented and less attuned to the aspirations of organised labour like its partners, the threat of a radical shift to a more hard-line Marxist-Leninist position has been nullified. And given Waghid's conclusion above that this is an 'ironic victory' for liberalism, it can therefore be reasonably argued that South Africa's project of a liberal conception of education will be sustained as part of the broader compliance with the terms of the country's liberal and egalitarian Constitution.

\section{References}

Abbey, R. (2005) "Is liberalism now an essentially contested concept?", New Political Science, 27 (4), 461-480.

Ake, C. (1993) "The unique case of African democracy", International Affairs, 69 (2), 239-244.

Bekker, S. (1998) "Book Review: Comrades in Business: Post-liberation politics in South Africa", Indicator South Africa, 15 (1), $46-48$.

Biko, S. (2005) I write what I like, edited by Aelred Stubbs C.R., Picador Africa: Johannesburg.

Buhlungu, S and Ellis, S. (2012) "The trade union movement and the tripartite alliance: a tangled history", in Sakhela Buhlungu and Malehoko Tshoaedi (eds) COSATU's Contested Legacy, HSRC Press: Cape Town.

Butler, A. (2013) "SACP chiefs must own up to not being Marxists", Business Day, May 17.

Chaskalson, A (2003) "From wickedness to equality: the transformation of South African law", International Journal of Constitutional Law, 1 (4), 590-609.

Cobber, J. A. M. (1987) "African values and human rights debate: an African perspective", Human Rights Quarterly, 9 (3), $309-339$.

Deveaux, M. (2003) "Liberal constitutions and traditional cultures: The South African customary law debate". Citizenship Studies, 7 (2), 161-180.

Dlamini, S. (2013) "Speech Delivered by COSATU President Comrade Sidumo Dlamini at the 4th International Police Symposium", Lusaka, Zambia, 27th - 30th April.

Dlamini, S. (2012) "COSATU's Message of Support to the 2012 NUM National Congress by the COSATU President - Comrade Sidumo Dlamini", Emperor's Palace, Ekurhuleni, 23rd - 27th May.

Dugard, J. (1998) "The new constitution: a triumph for liberalism? a positive view", in R, W. Johnson and David Welsh eds. Ironic Victory: Liberalism in Post-liberation South Africa, Oxford University Press: Cape Town.

Dworkin, R. (1989) "Liberal community", California Law Review, 77 (3), 479-504.

Enslin, P. and Horsthemke, K. (2004) "Can ubuntu provide a model for citizenship education in African democracies?". Comparative Education, 40 (4), 545-558.

Evans, M. (1999) "Is public justification central to liberalism", Journal of Political Ideologies, 4 (1), 117-136.

Friedman, M. (2003) "Cultural minorities and women's rights", in Autonomy, Gender, Politics: Studies in Feminist Philosophy, Oxford University Press: New York.

Galston, W. A. (1991) Liberal Purposes: Goods, Virtues, and Diversity in the Liberal State, Cambridge University Press: Cambridge.

Gaus, F. G. (2000) "Liberalism at the end of the century", Journal of Political Ideologies, 5 (2), 179-199.

Goldstone, R. J. (1997) "The South African Bill of Rights", Texas International Law Journal, 32:451-545.

Gray, J. (1978) "On Liberty, liberalism and essential contestability", British Journal of Political Science, 8 (4) 385-402.

Gutmann, A. (1985) "Communitarian critics of liberalism", Philosophy \& Public Affairs, 14 (3), 308-322.

Jordan, Z. P. (1996) "Harmony, an elusive objective", in The Star and SA Times International, June 12.

Lenin, V. (1999) 'Left-Wing' Communism: Infantile Disorder, Resistance Books: Chippendale, Australia.

Locke, J. (1993) Two Treatises of Government, edited by Mark Goldie, Everyman: London.

Macedo, S. (1991) Liberal Virtues: Citizenship, Virtue, and Community in Liberal Constitutionalism, Clarendon Press: Oxford. 
Makgoba, M W. (1998) "Opposition, difficulties, and tensions between liberalism and African thought", in R. W. Johnson and David Welsh (eds) Ironic Victory: Liberalism in Post-liberation South Africa Oxford University Press: Cape Town.

Mathebe, A. (2010) South African Mining Nationalisation, Xlibris Corporation: Bloomington, Indiana.

McKay, I. (2000) "The liberal order framework: a prospectus for a reconnaissance of Canadian history", The Canadian Historical Review, $81(4), 617-645$.

Mulhall, S. (1987) "The theoretical foundations of liberalism", European Journal of Sociology, 28 (2), 269-295.

Robinson, M. (2012) "Freedom, truth, democracy: citizenship and common purpose", Tenth Nelson Mandela Annual Lecture, delivered at Cape Town City Hall, August 5.

Rawls, J. (1999) A Theory of Justice, Revised Edition, Harvard University Press: Massachusetts.

Rawls, J. (1996) Political Liberalism, Columbia University Press: New York.

South African Communist Party (SACP). (2012) South African Communist Party Constitution, amended in July 2012. SACP: Johannesburg.

Simhony, A. (2003) "T. H. Green's community of rights: an essay on the complexity of liberalism", Journal of Political Ideologies, 8 (3), 269-287.

Susser, B. (1995) Political Ideology in the Modern World, Allyn and Bacon: Boston.

Taylor, C. (1991) "Cross-purposes: the liberal-communitarian debate", in Nancy Rosenblum (ed) Liberalism and the Moral Life, Harvard University Press: Massachusetts.

Waghid, Y. (2003) Community and Democracy in South Africa: Liberal Versus Communitarian Perspectives, Peter Lang: Berlin.

Waldron, J. (1987) "Theoretical foundations of liberalism", The Philosophical Quarterly, 37 (147), 127-150.

Ware, A. (1992) "Liberal democracy: one form or many?", Political Studies, 40, 130-145.

Welsh, D. (1998) "Introduction: the liberal inheritance", in R. W. Johnson and David Welsh (eds). Ironic Victory: Liberalism in Postliberation South Africa, Oxford University Press: Cape Town. 
